\title{
A Policy Move towards Sustainable Urban Transport in Pakistan: Measuring the Social, Environmental and Economic Impacts of Lahore BRT System
}

\author{
Irem Batool ${ }^{*}$, Muhammad Irshad ${ }^{* *}$ and Muhammad Abid $^{* * *}$
}

\begin{abstract}
We examine the impacts of a sustainable urban transport initiative, the first Bus Rapid Transit System launched in Lahore, Pakistan in year 2013. We measure the socio-economic and environmental impacts of the BRT using a questionnaire-based survey that collected information on customers' travel purpose, travel frequency, travel time, mode access, previous travel mode choices (pre-BRT) and travel mode choices at present. We estimate that, on average, a $B R T$ passenger saves about 46 minutes per day on a single trip. However, the modal shift from personal automobiles to the BRT system is found to be only 4 percent, i.e., significantly less than the shift found in other worldwide BRT systems. Moreover, we estimate the reduction in the number of private vehicles on roads, total distance travelled in $\mathrm{km}$ and associated travelling costs and, subsequently, the reduction in the carbon emissions. We conclude that the Lahore $B R T$ transit system needs to be expanded to other parts of the city.
\end{abstract}

\footnotetext{
* Department of Management Sciences, COMSATS University Islamabad, Sahiwal Campus, Pakistan. Email: irembatool@cuisahiwal.edu.pk

** Department of Management Sciences, COMSATS University Islamabad, Sahiwal Campus, Pakistan. Email: acuteacademy@gmail.com

*** Department of Mechanical Engineering, COMSATS University Islamabad, Wah Campus, Pakistan. Email:m.abid@ciitwah.edu.pk

The authors are thankful to Punjab Mass-transit Authority (PMA) for its support in data collection process from the Lahore Metro Bus passengers during their journeys.

This research was partially funded by the German Academic Exchange Commission (DAAD) under the German-Pakistani joint collaborative research project titled "Determinants of (De-) Regulation of Transport Markets (DAAD-No.57063183)" between Institute of Transport Economics (IVM), University of Muenster, Germany and COMSATS University Islamabad, Sahiwal Campus.

Authors are thankful to Prof. Dr. Gernot Sieg (Director, IVM) for his tremendous support and valuable suggestions during the entire period of research. The authors are also thankful to Punjab Mass-transit Authority (PMA) for its support in data collection from the Lahore BRT passengers during their journeys.
} 
Keywords: Urban transport, Bus Rapid Transit System, travel time saving, vehicle costs saving, environmental emissions reduction, Lahore, Pakistan.

\section{JEL Classifications: R49.}

\section{Introduction}

Sustainable urban transportation is at the core of sustainable urban living; it allows people to move easily and interact socially, and minimizes negative externalities on public health and environment both for present and future generations. Urban transportation can be categorized into formal and informal modes: formal transportation modes are typically those which are designed, planned and provided by the city government such as walking and biking lanes, taxis, buses, trucks and rail, while informal modes are administered by the private sector such as "paratransit", "low-cost transport" "third world transport" carriers including mini-vans, two or three-wheel rikshaws and chingchies (Cervero, 2000).Formal urban transport is much popular in Eastern Europe and East Asia (comprising 45 percent of total trips), whereas it is less popular in Sub Saharan Africa (comprising only 5 percent of the total trips) because of unsatisfactory passenger's mobility demands (Dorina \& Dominic, 2015). Consequently, informal modes of transport serve as "gap fillers" in these places (Mohareb \& Felix, 2017). Besides, many commuters use their own private vehicles and become vehicle dependent, even in developing countries (Ramadan, 2016); the number of registered vehicles has been increased to 1776 million vehicles in 2015 from 982 million in 2005 , and is expected to rise up to a potential 2.6 billion vehicles by the year 2050 (WHO, 2015; Wright \& Hook, 2007).

The rapid growth in motorization and vehicle dependency has created various problems such as traffic jams, travel uncertainty and delays, traffic accidents, increased energy (oil/gas) consumption, increased vehicle costs, urban air pollution and economic losses due to health issues and resultant foregone wages (Kogdenko, 2011; Greene \& Wegener, 1997). Developing economies especially in Asia and Africa are searching for sustainable transport options (Haghshenas, Vaziri, \& Gholamialam, 2013). According to Litman, (2017) public transit systems have the potential to resolve various traffic issues like traffic congestion, 
parking congestion, traffic accidents, road and parking infrastructure costs, automobile costs to consumers, inadequate mobility for nondrivers, excessive energy consumption and pollution emissions. Pojani \& Stead (2015) have critically examined the nine commonly considered options for sustainable urban transport in cities, especially those in the developing countries, and finds the Bus Rapid Transit (BRT) system is a viable policy option for large cities as it can serve approximately 45,000 passengers per hour per direction.

BRT operates on a separated right-of-way infrastructure that provides frequent, rapid operations in busy economies (Currie \& Delbosc, 2014; Hensher \& Golob, 2008; Wright \& Hook, 2007; Yazici et al., 2013). Lautso et al., (2004) contends that BRT systems provide services that match the three legs of sustainability: social, economic and environmental sustainability. BRT systems help replace larger numbers of single occupancy vehicles (e.g., private cars and motorcycles) with a smaller number of higher occupancy vehicles such as buses and vans, which ultimately reduce vehicle costs and environmental pollution (Baghini et al., 2014). BRTs enhance urban quality of life in four ways: 1) they reduce travel time, 2) diminish air pollution and greenhouse gas (GHG) emissions, 3) promote traffic safety and 4) increase physical activity (Carrigan, et al., 2013). Safety benefits and increases in physical activity through walking are additional benefits of using BRT system (Carrigan, et al., 2013). BRT systems are ten times safer per kilometer than traveling by car according to one study (Litman, 2016). Further, BRT systems possess unique features as compared to the old transport systems like Intelligent Transportation System technologies that have increased operational efficiency and service quality. Although the BRT system is more cost effective than rail transit systems, it also requires large capital and construction investments in BRT infrastructure (Deng \& Nelson, 2012; Hensher \& Golob, 2008). However, mass transit systems are generally subsidized to promote social inclusion on account of social welfare benefits (Cropper \& Bhattacharya, 2012; Serebrisk et al., 2009).

Around the world, people are moving from conventional transport systems to BRT. At present, 206 cities worldwide (including 42 Asian, 59 European, 67 Latin American, 29 North American, 4 African and 4 Oceanian cities) are serving more than 34 million passengers per 
day on 5,569 km routes through BRT systems (shown in Figure 1 below). Brazil is a leader in BRT, as 34out of the 67 cities in Latin America with BRT are located there.

Figure 1: Number of BRT systems worldwide

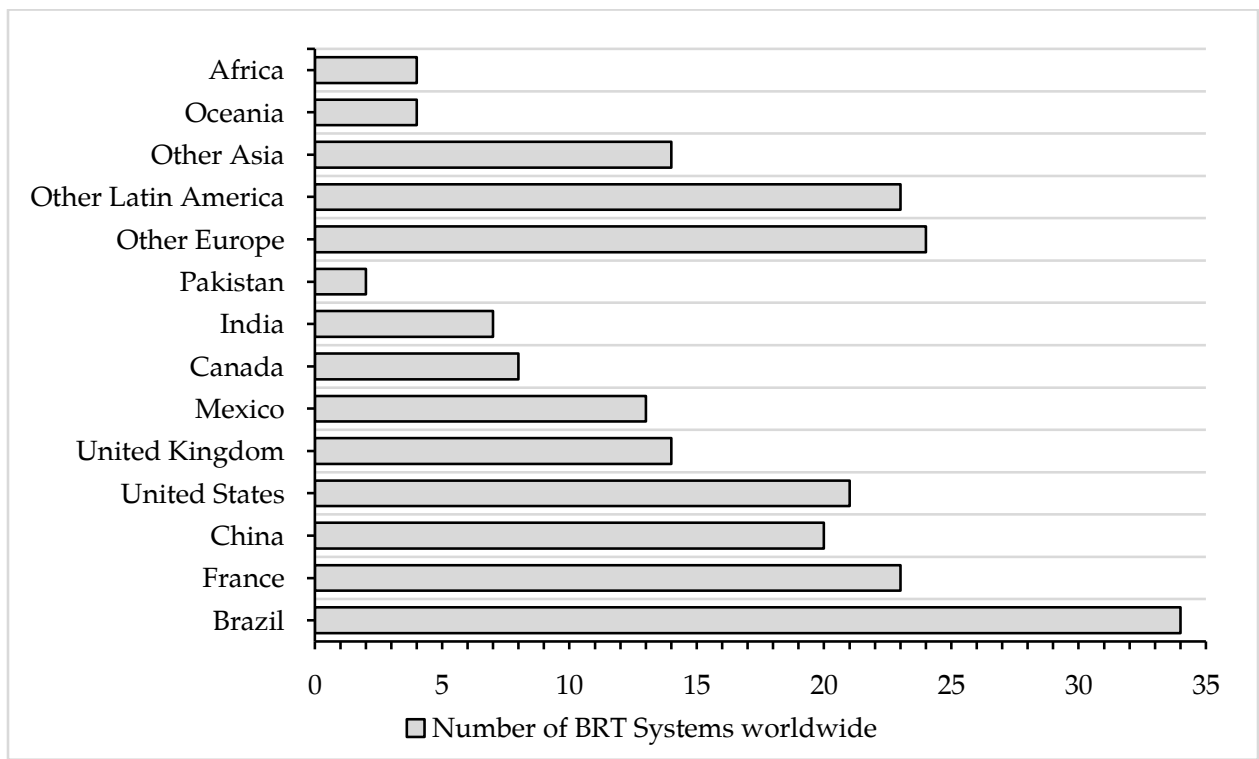

Source: www.brtdata.org.

BRT systems in Bogotá, Mexico City, Johannesburg, and Istanbul, have improved quality of life in four key areas: travel time saving, vehicle costs saving, reducing greenhouse gases (GHG) and local air pollutant emissions, and have led to improvements in traffic safety and higher physical activity (Carrigan, et al., 2013).

\section{Urban Transport Problems and Lahore BRT System}

Pakistan is the sixth most populous country in the world and its urbanization share has been reached up to 40 percent of the total population in year 2016. Lahore, the capital city of province Punjab, is situated in the north eastern part of Pakistan and is the second largest city in the country with 9.54 million estimated population in 2015 (Bureau of Statistics, 2015). It is the 39th largest city among the list of urban agglomeration cities with more than 5 million inhabitants in year 2014 (United Nations, 2014). The estimated transport demand in Lahore was 
about 17.7 million trips per day, which includes 8 million short walking journeys, 3.3 million trips by motorcycles or pedal cycles, 2.9 million trips by private car, and about 3.4 million trips by public transport during the year 2007 (ALMEC, 2012). Figure 2 illustrates this breakdown.

\section{Figure 2: Estimated transport trips demand per day in Lahore}

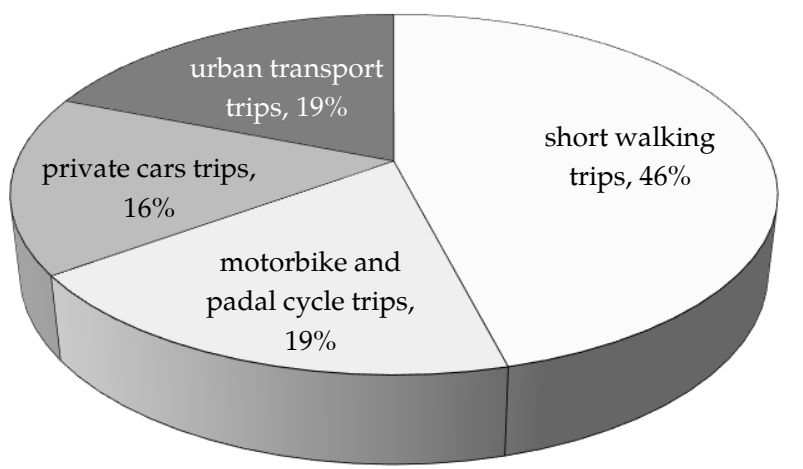

$\square$ short walking trips

$\square$ motorbike and padal cycle trips

$\square$ private cars trips

$\square$ urban transport trips

Source: ALMEC (2012).

Lahore's urban transport system currently comprises both formal and informal modes of transport such as Lahore Transport Companies (LTC) buses, mini vans, rickshaws, motorbikes, taxis and private cars. The current public transport services in Lahore are characterized by inappropriate operational timetables, inefficient use of road space and poor condition of public transport facilities (including bus terminals and buses) which combine to pose a severe challenge to urban connectivity. The factors responsible are escalated travel demand, inadequate capacity, improper governance, and poor urban transport planning (Dainichi, 2010; Imran, 2009). Like other developing economies, urban transport problems in Pakistan have been partially addressed by investing in roads and highways, while little attention has been paid to the provision public transport services at large (Kitamura \& Jamilah, 2009). The implementation of these suboptimal transport policies and unfavorable public transport conditions has shifted passengers from high occupancy vehicles (buses and vans) to single occupancy vehicles (private cars). Consequently, the use of automobiles in Lahore has tripled over a decade 
i.e., 0.9 million in 2003 to nearly 4 million in 2014, significantly increasing urban congestion (Bureau of Statistics, 2015). In particular, this rapid increase in automobiles has triggered road congestion, fuel shortages, road traffic accidents and greater environmental pollution (Government of Pakistan, 2015-16). The transport sector has become the largest consumer of oil in the country (55 percent of total consumption), and oil import bills have reached up to $\$ 7.6$ billion dollars (17 percent of the total import bill) in 2016 (SBP Annual Report 2015-16). Accordingly, producing a given amount of economic output requires more than twice the amount of $\mathrm{CO}_{2}$ emissions from transport as compared to regional averages. The economic loss to Pakistani road users and injuries is estimated to be more than Rs100 billion per year (Ahmed, 2007). Another important factor is the travel time unreliability (uncertainty about how long a trip will take, and unexpected delays) due to traffic congestion that becomes common during peak and rush hours, imposes additional costs to travelers and society. Ali et al. (2014) found that about PKR 1 million are lost daily due to traffic congestion in Karachi only.

Acknowledging these urban transport problems and the potential benefits of the BRT system realized globally, the Government of Punjab (Pakistan)established the Punjab Mass-transit Authority (PMA) with the aim to provide safe, efficient and comfortable urban transport in the major cities of Punjab. Lahore Metrobus System was its very first BRT system, initiated in February 2013. It is a $27 \mathrm{~km}$-long route running in the NorthSouth direction crossing at the center of Lahore connecting the Gajjumata and Shahdara bus terminals. Figure 3 shows the Lahore BRT corridor. Typically, a BRT system should be launched at such locations of the city where traffic volume is almost 2000 to 4000 passengers per hour per direction (Wright \& Hook, 2007). In Lahore, the traffic volume is estimated to be between 7000-9000 per hour during off-peak to peak hours.

Lahore BRT has a maximum speed limit of 31 miles per hour, while its speed in commercial areas is limited to16 miles per hour. It offers daily service, running from 06:15-22:00 hours. The transit signal priority at the road intersections reduces delays at traffic lights. Like other BRT systems in the world, Lahore BRT operations are also administered via modern technologies that mainly focus on speeding up vehicle movements and passenger boarding by the application of 
measures such as Intelligent Transportation System (ITS), Passenger Information System (PIS), off-board ticketing and an Automated Fare Collection (AFC) System. According to the PMA estimates, daily ridership is about 130,000 trips, which cover approximately 1.7 percent of overall motorized trips in the city in year $2015^{1}$ (PMA 2015).

The utility of any public transport system is derived from its affordability, accessibility and the quality of services (Maunganidze, 2011). Wan et al. (2016) found that service frequency, speed, and on-time performance critically affect satisfaction level among riders across all routes, and service quality and accessibility play an important role in attracting new passengers to BRT systems. Modal shifts to BRT are also influenced by the traveler's demographic and socio-economic attributes, like gender and age, and trip-related attributes, such as trip purpose, travel time savings, trip costs, trip distances, and weekly travel frequencies (Wang Y. W., 2013). Hess (2009) suggests that the walking distance to public transit has a significant influence in predicting ridership frequency. According to Katrin (2017), each additional five minutes in perceived walking time to public transit decreases ridership frequency by 5 percent for non-drivers and by 25 percent for drivers in San José, California (USA). This implies that policy makers should not only focus on provisioning the transit systems, but also focus on understanding the determinants of the mode choice access and essential service parameters to be considered to achieve success.

Currently, the BRT system is running in 3 major cities of Pakistan namely, Lahore, Islamabad, and Multan. The Government of Pakistan is considering the expansion of existing BRT networks and the introduction of transit systems in additional cities. It is therefore important to evaluate whether the Lahore BRT has provided social, environmental and economic benefits.

\footnotetext{
${ }^{1}$ Since 2015, ridership of Lahore BRT has continued to rise, now reaching up to 179,000 riders per day, and about 250 million passengers have travelled by Lahore BRT since its inception in year 2013 (as reported by PMA website).
} 
Figure 3: Lahore BRT corridor

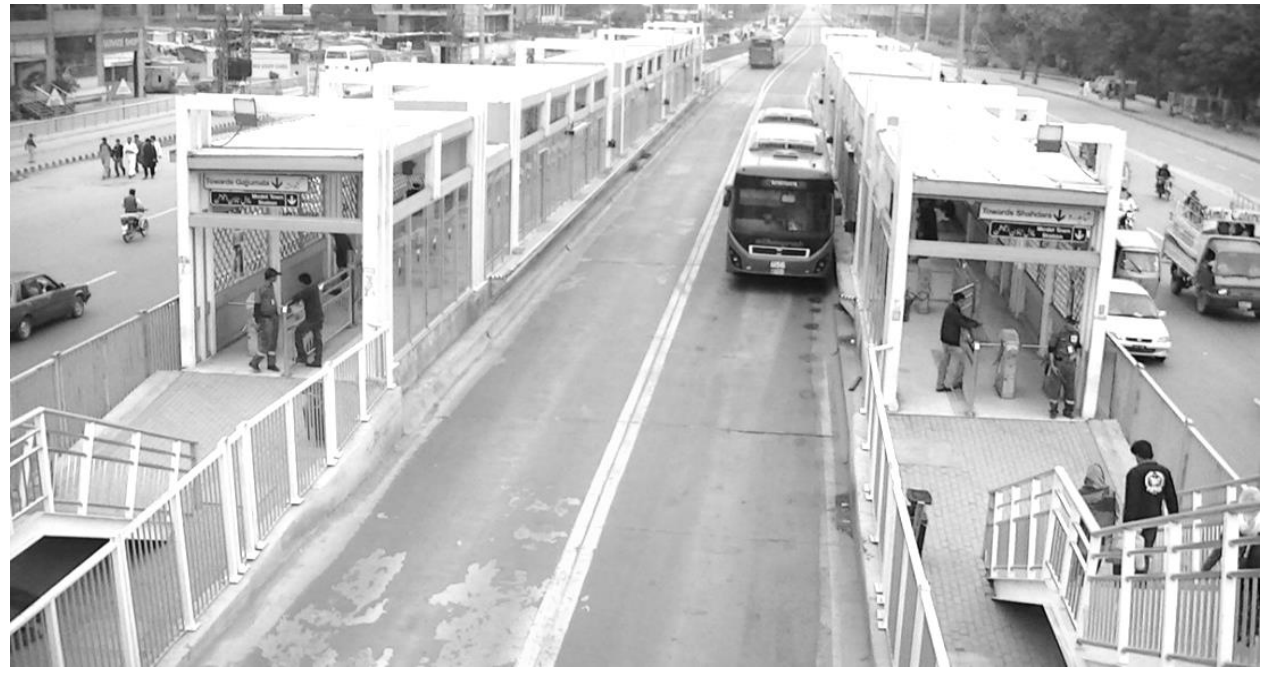

Source: Authors' Photograph.

Our study attempted to answer the following questions:

Q1: Does Lahore BRT save travel time?

Q2: Does Lahore BRT reduce the vehicle miles travelled?

Q3: Does Lahore BRT attract passengers away from personal car use to Lahore BRT?

Q4: Does Lahore BRT reduce environmental emissions?

Q5: Does Lahore BRT promote social integration?

Q6: Does Lahore BRT help boost physical activity among passengers?

We addressed these questions and evaluate the performance of the Lahore BRT system on the basis of the established parameters discussed in the literature (Wan, 2016; Wang Y. W., 2013; Hess, 2009; Katrín, 2017; Maunganidze L. , 2011). To the best of our knowledge, only Mansoor et al.(2016) have analyzed the Lahore BRT up to now; these authors have gathered public opinions and discussed the positive impacts of the Lahore BRT in pre- and post-implementation periods. However, they did not attempt to quantify the socio-economic and environmental impacts such as travel time savings, vehicle costs savings, reductions in vehicle distance traveled and reductions in environmental emissions. 


\section{Data and Research Methodology}

Wright and Hook (2007) suggested that the customer's opinion is perhaps the single most important variable that measures the utility of public transport projects. A significant amount of research has evaluated public transit systems based on both passenger perceptions and transit agency performance indicators (Eboli \& Mazzulla, 2011; dell'Olio, 2010; Shreya \& Debapratim, 2013).

Our study is based upon questionnaire-based survey information that was collected in 2015 from passengers who have travelled on the Lahore BRT. We used the methodology developed by Cochran (1963) to determine a representative sample size for the desired level of precision, desired confidence level and the accurately represented attributes of the target population. Our analysis found that a sample of 385 respondents was sufficient to study the target population of about 13,000 riders. In the present study, we have surveyed a total 760 passengers i.e. larger than the required as per this criterion, so we are confident that our sample size is large enough to study the attributes of the target population.

Using primary data, we identify Lahore BRT passengers' transport patterns and estimate total time saving, vehicle cost saving, environmental emission reduction and associated socio-economic benefits. Furthermore, we outline recommendations for the improvement and better utilization of the Lahore BRT system.

\subsection{Survey Design}

Our study adopts the questionnaire from the studies of Dickey (2008) and Deng \& Nelson (2012). We distributed 850 questionnaires in total out of which 760 were usable for our analysis. Since travel behavior of passengers fluctuates between weekdays and weekends, responses have been collected on three weekdays $\left(20^{\text {th }}, 23^{\text {rd }}\right.$ and $24^{\text {th }}$ February 2015) and two weekend days (21 ${ }^{\text {st }}$ and $22^{\text {nd }}$ February 2015) at different times (Pas \& Sundar, 1994; Kitamura \& T, 1987; Hanson \& Huff, 1982; Hanson \& Huff, 1986; Huff \& Hanson, 1990; Aguiléra, Massot, \& Proulh, 2009).The survey was conducted during the morning rush, noontime, afternoon and evening times to minimize potential biases created by sampling time. Also, there were no significant public events (such as national or provincial sports 
festivals) during our sample time period, which could have impacted the validity of our sample (Deng \& Nelson, 2012).

The travelers were randomly selected during their journey and requested to fill the questionnaires. The survey had a high response rate (89.4 percent). Almost 60 percent of the questionnaires were filled by the travelers themselves while the remaining 40 percent were completed through interviews at entry and exit points of the Lahore BRT stations.

\subsection{Methodology}

The survey responses on passengers' demographic and socioeconomic (gender, age, income, occupation) factors, trip related attributes such as trip purpose, trip frequency, trip cost, mode choices in the past (before the introduction of Lahore BRT) and mode choices at present, travel time savings and accessibility features were used to evaluate the Lahore BRT performance. Other BRT social impacts such as improved physical activity, reduction in travel time, reduction in road congestion, and reduction in vehicle miles traveled were also estimated. Estimated reductions in vehicle miles traveled were utilized to calculate the reduction in environmental emissions and vehicle costs saving.

According to the US Environmental Protection Agency, $\mathrm{CO}_{2}$ emissions of a typical passenger vehicle from a gallon of gasoline are $8,887 \mathrm{~g}$ and $\mathrm{CO}_{2}$ emissions from a gallon of diesel are 10,180 g (EPA, 2014). The emission of carbon dioxide contents from an average passenger vehicle per mile is calculated from the amount of $\mathrm{CO}_{2}$ emitted after burning one gallon of fuel and the average mileage i.e., miles per gallon (MPG) as defined by:

$$
\mathrm{CO}_{2} \text { emissions per mile }=\frac{\mathrm{CO}_{2} \text { per gallon }}{\mathrm{MPG}}
$$

In this way, $\mathrm{CO}_{2}$ emissions per mile are estimated to be $411 \mathrm{~g}$ per mile, based on 21 miles per gallon estimates. Next, total annual $\mathrm{CO}_{2}$ reduction can be calculated by multiplying it with the estimated reduction miles per year:

Annual $\mathrm{CO}_{2}$ emissions reduction $=\frac{\mathrm{CO}_{2} \text { per gallon }}{\text { MPG }} \times$ miles reduced per year 
We follow Litman's (2015) methodology to measure the economic value of travel time saving, vehicle cost savings, and pollution cost savings. Economic value of travel time savings is calculated by multiplying the number of hours saved with 35 percent of the average hourly wage rate in Pakistan. The economic value of vehicle cost saving is calculated by multiplying the number of reduced vehicle miles traveled with the value of estimated vehicle cost per mile (i.e., \$0.35 per mile). Similarly, the economic value of pollution costs saving is calculated by multiplying the number of reduced vehicle miles traveled with the cost of pollution saved per mile (i.e. $\$ 0.05$ per mile).

\section{Survey Outcomes and Discussion}

\subsection{Demographic Profile and Service Utilization Characteristics of Lahore BRT Users}

Lahore BRT users are classified by gender, age, education, income level and occupation as shown in Appendix A. Among the survey respondents, 80 percent were male, and the majority were young, aged 18 to 34 years. The majority of the respondents possess at most a metric degree (10 years of education) and belonged to lower income groups. The BRT costs PKR 20 per trip irrespective of distance covered, i.e. comparatively cheaper than other modes of transport in the city. According to the survey results, more than 50 percent of the respondents utilize Lahore BRT more than once a day while 14 percent of them use this service 4 to 6 times in a week and 11 percent of the respondents use this service 1 to 3 times per month. A majority of the respondents had been utilizing this service for some time, implying that it has become a regular transport mode for their return trips and that they are generally satisfied with its services (see in Appendix A.) Seda et al. (2017) find that access mode variables are more important than total travel time for traveler's satisfaction, confirming the significant role of access in multi-modal travels. The majority of respondents ( 47 percent of the total) access Lahore BRT stations by walking, while 24 percent use vans to get to the stations.

\subsection{Travel Purpose and Social Integration}

Generally, people prefer to use their own private cars or rented cars to visit family and friends (Adeel, Yeh, \& Zhang, 2016). In the case of 
the Lahore BRT, more than 50 percent of passengers use the service for traveling to study and work, whereas 15 percent are traveling in order to visit friends or family (Figure 3). This implies that the Lahore BRT is not only providing commuting services for economic activities but also supporting social activities among the people living along the corridor.

\section{Figure 4: Main purpose of Lahore BRT trip}

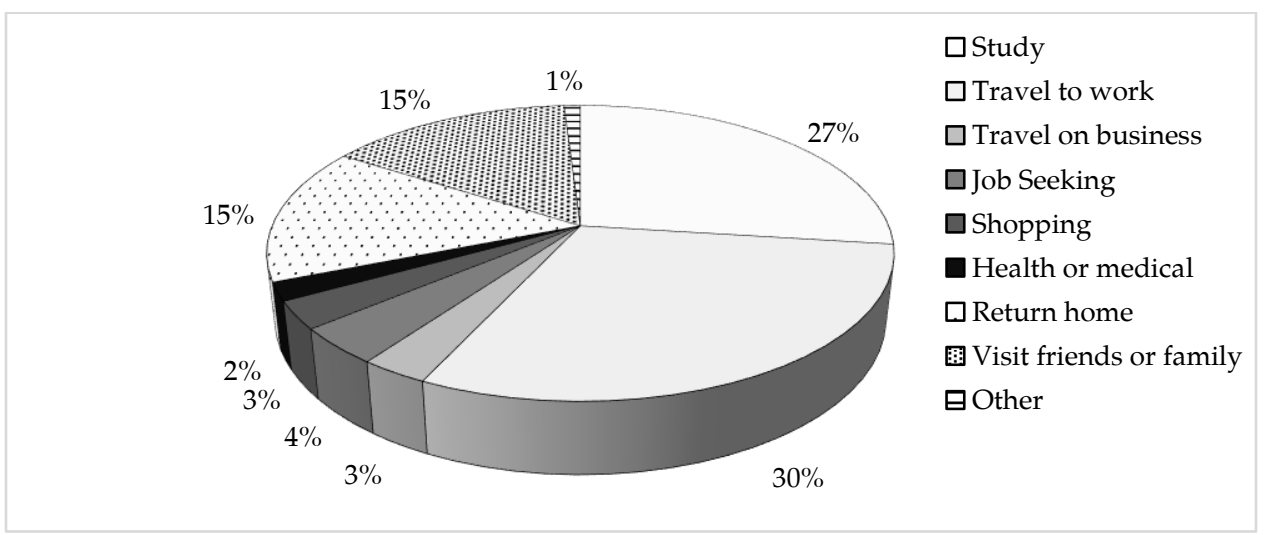

Source: Authors' estimates.

\subsection{Improved Physical Activity}

Mass transit systems are playing a vital role in improving physical activities, as passengers need to also walk to complete their journey (Chad et al., 2017). Survey results show that 47 percent of the respondents get access to Lahore BRT stations by foot (as shown in Figure 5), and similarly 48 percent of the total travelers complete their journey by walking to their final destination (Figure 6). In this way, the Lahore BRT also promotes physical activity among the passengers. 
Figure 5: Transport mode used to get final destination

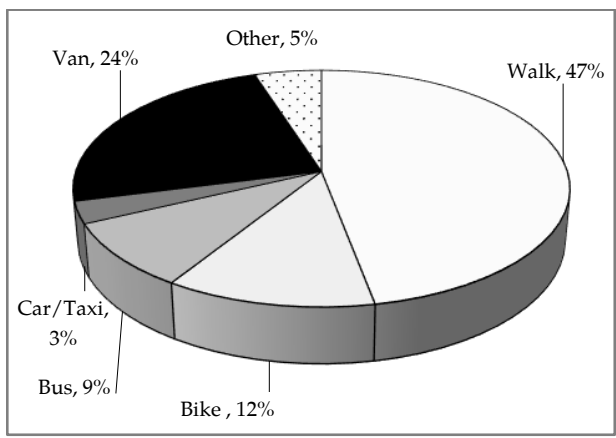

Source: Authors' estimates.
Figure 6: Transport mode used to reach on final access to the Metrobus station

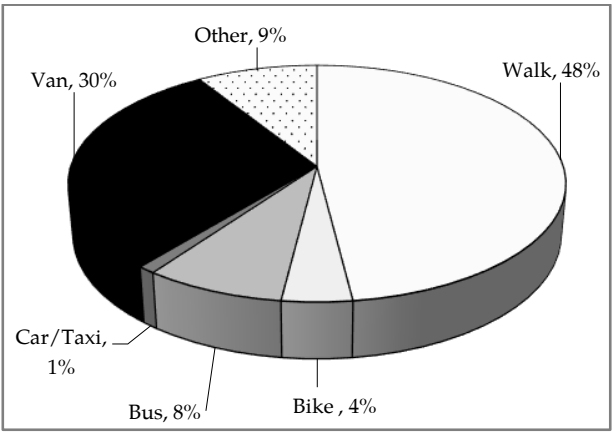

Source: Authors' estimates.

\subsection{Reduction in Travel Time}

Travel time saving is typically the primary benefit of any transport project. According to the General Manager Operations of Punjab Metrobus Authority, the time it takes to travel16.8 miles from the Gajjumata station to the Shahdra station was reduced from one hour and 40 minutes before the inception of Lahore BRT to 55 minutes after its inception (PAKSTRAN). Our survey responses show that the majority of respondents complete their Lahore BRT journey within 12-36 minutes (Figure 8). The commercial speed of Lahore BRT is 16.2 miles per hour (PMA), and the average distance traveled by each passenger in a day is 6.5 miles per trip, or 13 miles in a day if a typical passenger returns by the same mode of transport.

Figure 7: Total time of Lahore BRT trip

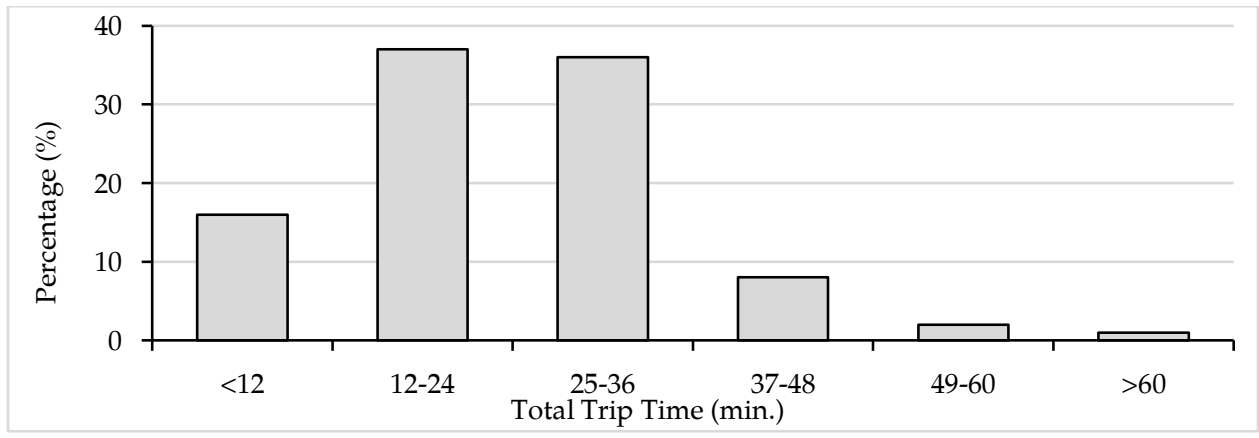

Source: Authors' estimates. 
Figure 9 shows that about 35 percent of the respondents save about 21-40 minutes per trip by riding on MBS, and 24 percent of the respondents save about 11-20 minutes per trip, while the remainder save less than 10 minutes per trip. So, on average a passenger saves about 23 minutes per trip or 46 minutes per day if using the same service again when returning home.

Figure 8: Travel time saving with the Lahore BRT

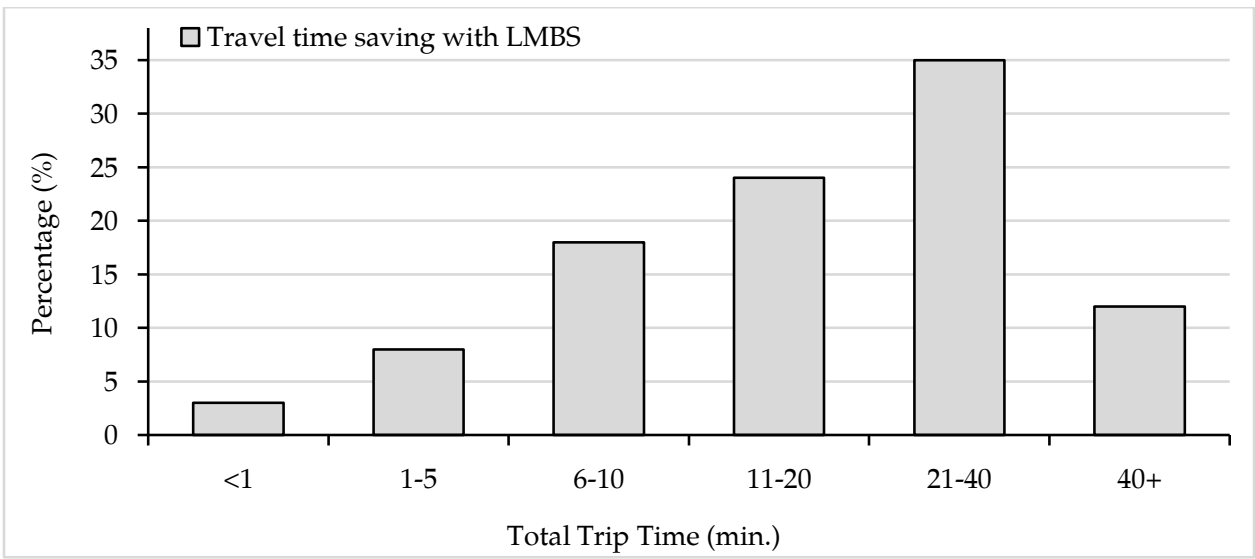

Source: Authors' estimates.

Aggregating our results, we estimate that each passenger who used the service twice a day saved about 12 days of travel time in2015. Extrapolating to all passengers (approximately 130,000) of Lahore's BRT, a total of about 18 million hours have been saved in the year 2015 (Table 1). This saved travel time has the potential to be utilized for other social and economic activities.

Table 1: Travel time savings and value calculations

\begin{tabular}{|c|c|c|c|c|c|}
\hline (1) & $(2)$ & (3) & (4) & (5) & (6) \\
\hline $\begin{array}{l}\text { Avg. time } \\
\text { saving per } \\
\text { commuter } \\
\text { per trip }\end{array}$ & $\begin{array}{l}\text { Total } \\
\text { time } \\
\text { saved per } \\
\text { day (hours) }\end{array}$ & $\begin{array}{l}\text { Time } \\
\text { saved (days } \\
\text { per } \\
\text { commuter } \\
\text { per annum }\end{array}$ & $\begin{array}{l}\text { Total } \\
\text { time saved } \\
\text { (hours) per year } \\
\text { by all } \\
\text { commuters }\end{array}$ & $\begin{array}{l}\text { Value } \\
\text { of total time } \\
\text { saved } \\
\text { per year } \\
\text { (USD) }\end{array}$ & $\begin{array}{l}\text { Value } \\
\text { of total time } \\
\text { saved } \\
\text { per year } \\
\left(\mathrm{PKR}^{*}\right)\end{array}$ \\
\hline 23 Minutes & $49,833 \mathrm{hrs}$ & 12days & $18,046,491$ & $\$ 7.77$ million & 814.19million \\
\hline
\end{tabular}

${ }^{*}$ Exchange rate: PKR 104.8 per USD in 2015.

Source: Author Calculations (based on travel time saving estimates) 
The average monthly wage rate is US $\$ 255$ in Pakistan (Statista, 2012). There are 26 working days in a month translating into an average wage rate of $\$ 1.23$ per hour. The value of total travel time saved is worked out by multiplying the number of total hours saved (travel time) with 0.35 of the hourly wage rate. In this way, the value of travel time saving is estimated to be US\$ 7.77 million and PKR 814.19 million rupees for the surveyed year 2015 (Table 1).

\subsection{Modal Shift to Lahore BRT}

Globally the modal shift from autos to BRT ranges generally between 9 and 40 percent (Figure 9), and several factors are responsible for this shift such as cost of riding, safety, availability of alternatives, travel obstacles along with footpaths, reliability, frequency, cleanliness, comfort, crowding, information, ticketing, safety, security, speed, fare, accessibility and staff courtesy etc. (Wan, 2016; Hess, 2009).

The observed modal shift from personal autos to Lahore BRT is only 4 percent (Figure 10). However, the literature has found that even a fractional mode shift towards the use of public transport or nonmotorized transport from motorized ones would have immense impacts in terms of environmental emission reduction (Wright \& Fulton, 2005).

Figure 9: Worldwide Modal shift from Auto to BRT System

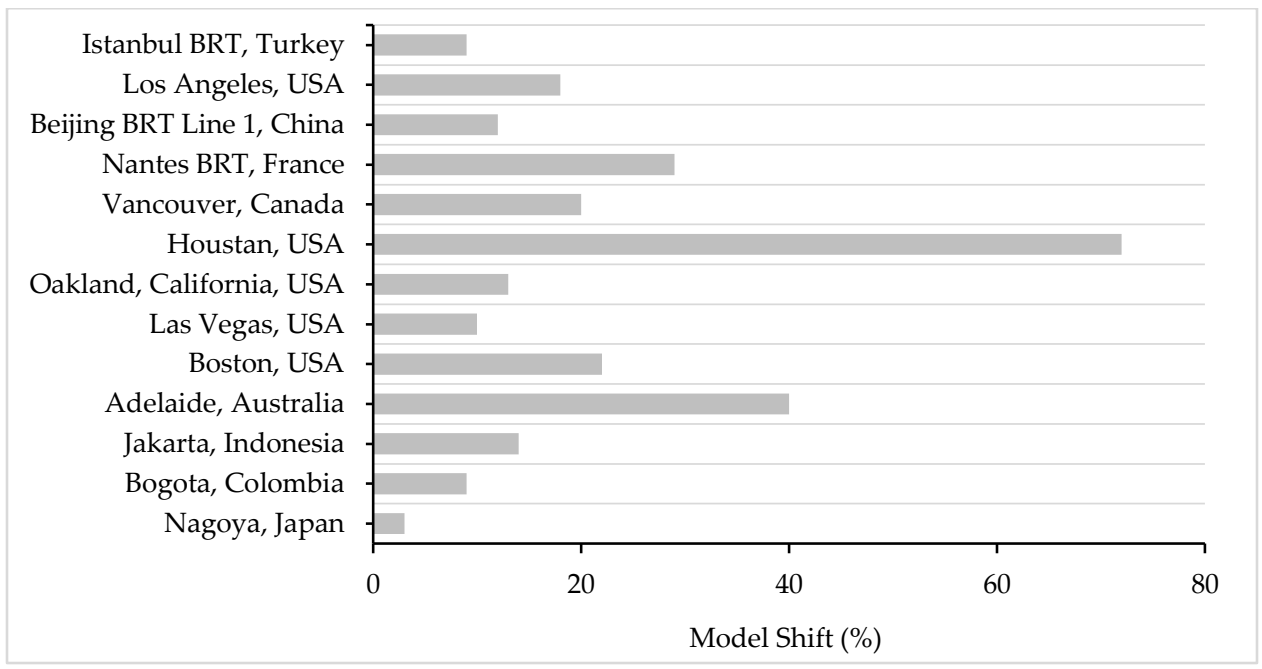

Source: Wang (2013). 
Figure 10: Travel Modal shift to Lahore BRT

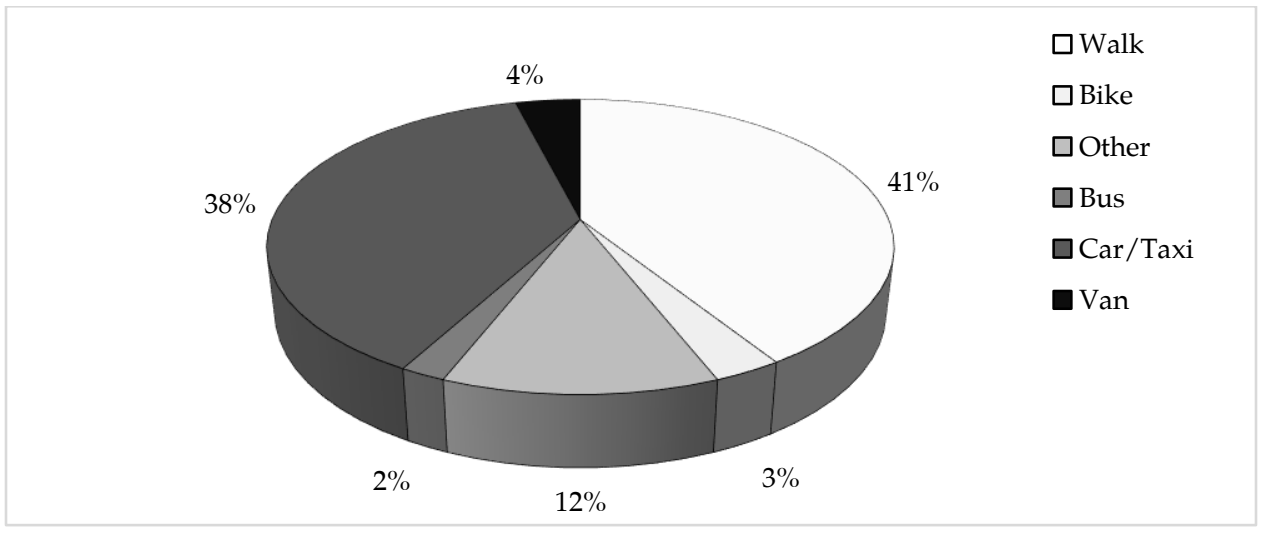

Source: Authors' estimates.

\subsection{Reduction in Private Vehicles and Road Congestion}

We estimate reductions in private vehicles and private vehicle costs based on the observed modal shift and passengers' car ownership (see Table 2). According to the survey results, 4 percent passengers have shifted from personal autos to Lahore BRT (Figure 11). Ridership is about 130,000 per day, so we estimate a reduction of about 5,200 automobiles per day on the roads due to Lahore BRT operations. A single passenger of Lahore BRT travels on average $10.4 \mathrm{~km}$ per trip daily and there is a reduction of approximately 33.6 thousand vehicle miles per day by Lahore BRT passengers.

Survey results show that 16 percent of passengers have the "alternative mean to travel for this trip i.e., their own personal car" (see Table 1, Appendix A), but they prefer to travel by Lahore BRT. Under this alternate scenario, we estimate a reduction of approximately 20,800 autos per day on the road and about 134.4 thousand vehicle miles per day (Table 2). The Lahore BRT services may potentially save these passengers from traffic jams and road accidents. Further, when automobile clients shift to the transit system, they save fuel costs, maintenance costs, parking and insurance costs, and ownership costs as suggested in Litman (2015). These vehicle costs in total are almost $\$ 0.30$ dollar per mile at off-peak and $\$ 0.40$ dollar per mile at urban peak times. This average rate $(\$ 0.35$ dollar) is multiplied with the estimated reduction in vehicle miles 
traveled in order to calculate the economic value of vehicle costs saving for passengers who opted for the Lahore BRT.

Our estimated results show that each passenger of the Lahore BRT has saved about $\$ 33$ per year amounting to a total of $\$ 4.3$ million per year for all passengers of Lahore BRT (based on observed 4 percent modal shift in survey results). If instead we assume the alternate scenario based on the 16 percent of riders who own a car, passengers have saved about $\$ 17.2$ million dollars per year (calculations are shown in Table 2).

\subsection{Reduction in Environmental Emissions}

The rapid increase in vehicles, excessive consumption of fuel, smoke clouds and dust are negatively impacting the natural aesthetics as well as the environment of cities and having serious health impacts. According to the WHO assessment, about 92 percent of the world population lives in the areas where the minimum WHO environmental standards are not met. Motorized vehicles are the largest contributor (59 percent) in anthropogenic $\mathrm{CO}_{2}$ emissions worldwide, particularly in urban areas. In Pakistan, the transport sector is the largest consumer (i.e. 55 percent) of petrol and petroleum products and is therefore the largest contributor of related carbon emissions(Government of Pakistan, 2016).In the case of Lahore, the road transport sector produces 92.8 percent of total transport related $\mathrm{CO}_{2}$ emissions(EGC, 1998; Zaman, 1999).

Table 2: Estimated vehicle miles reduction and costs saving

\begin{tabular}{|c|c|c|c|c|c|c|}
\hline (1) & $(2)$ & (3) & (4) & (5) & (6) & (7) \\
\hline Scenarios & $\begin{array}{l}\text { No. of } \\
\text { vehicles } \\
\text { reduced per } \\
\text { day }\end{array}$ & $\begin{array}{l}\text { Average } \\
\text { Distance } \\
\text { travelled } \\
\text { (per trip) }\end{array}$ & $\begin{array}{l}\text { Average } \\
\text { reduction in } \\
\text { vehicle miles } \\
\text { travelled } \\
\text { (per day) }\end{array}$ & $\begin{array}{l}\text { Average } \\
\text { vehicle costs } \\
\text { saving } \\
\text { (per day). }\end{array}$ & $\begin{array}{l}\text { Annual } \\
\text { vehicle costs } \\
\text { saving* } \\
\text { (USD) }\end{array}$ & $\begin{array}{l}\text { Annual } \\
\text { vehicle costs } \\
\text { saving** } \\
\text { (PKR } \\
\text { Rupees) }\end{array}$ \\
\hline $\begin{array}{l}\text { Mode shift } \\
(4 \%)\end{array}$ & 5,200 autos & $10.4 \mathrm{~km}$ & 33604 & $\$ 11,761.3$ & $\$ 4.3$ million & $\begin{array}{l}\text { PKR } 0.5 \\
\text { billion }\end{array}$ \\
\hline $\begin{array}{l}\text { Car } \\
\text { Alternative } \\
(16 \%)\end{array}$ & 20,800 autos & $10.4 \mathrm{~km}$ & 134,415 & $\$ 47,045.3$ & \$17.17 million & $\begin{array}{l}\text { PKR } 1.8 \\
\text { billion }\end{array}$ \\
\hline
\end{tabular}

*Vehicle cost saving in dollars is $\$ 0.35$ per mile as suggested in Litman (2015);

** Vehicle cost savings in PKR is calculated using an exchange rate of PKR104.8 rupees per 1 USD in 2015.

Source: Authors' Calculations (based on average trip distance travelled by passengers). 
BRT systems worldwide have reduced greenhouse gas emissions (Baghini et al., 2014; Carrigan, et al., 2013). We estimate a total reduction in $\mathrm{CO}_{2}$ emissions of about 14 tonnes per day and 5.041 thousand tonnes per annum based on the 4 percent modal shift we observe for the Lahore BRT system. However, if we assume that there is the reduction of about 20,800 car trips (based on the 16 percent of passengers who own a car), then we estimate a reduction of about 55 tonnes $\mathrm{CO}_{2}$ reduction per day and 20.2 thousand tonnes $\mathrm{CO}_{2}$ reduction per annum in Lahore (see Table 3).

Table 3: Reduction in environmental emissions

\begin{tabular}{|c|c|c|c|c|c|c|}
\hline (1) & (2) & (3) & (4) & (5) & (6) & (7) \\
\hline Scenarios & $\begin{array}{l}\text { No. of cars } \\
\text { reduced per } \\
\text { day }\end{array}$ & $\begin{array}{l}\text { Average } \\
\text { distance } \\
\text { travelled } \\
\text { (per trip) }\end{array}$ & $\begin{array}{l}\text { Average } \\
\text { reduction } \\
\text { in vehicle } \\
\text { miles } \\
\text { travelled } \\
\text { (per day) }\end{array}$ & $\begin{array}{l}\text { Average } \\
\text { environmental } \\
\text { emissions } \\
\text { reduction per } \\
\text { day. }\end{array}$ & $\begin{array}{l}\text { Annual } \\
\text { l reduction } \\
\text { in Pollution } \\
\text { costs }^{\mathrm{TM}} \\
\text { (USD) }\end{array}$ & $\begin{array}{l}\text { Annual } \\
\text { reduction } \\
\text { in Pollution } \\
\text { costs } \\
\text { (PKR }_{\text {Rupees)* }}^{*}\end{array}$ \\
\hline $\begin{array}{l}\text { Mode shift } \\
(4 \%)\end{array}$ & 5200 & $10.4 \mathrm{~km}$ & $\begin{array}{l}33,604 \\
\text { miles }\end{array}$ & 14 tonnes & $\begin{array}{l}\$ 0.61 \\
\text { million }\end{array}$ & $\begin{array}{l}\text { Rs. } 64.27 \\
\text { million }\end{array}$ \\
\hline $\begin{array}{l}\text { Car } \\
\text { Alternative } \\
(16 \%)\end{array}$ & 20800 & $10.4 \mathrm{~km}$ & $\begin{array}{l}134,415 \\
\text { miles }\end{array}$ & 55 tonnes & $\begin{array}{l}\$ 2.45 \\
\text { million }\end{array}$ & $\begin{array}{l}\text { Rs. } 257.08 \\
\text { million }\end{array}$ \\
\hline
\end{tabular}

${ }^{\text {TM} A v e r a g e ~ c a r ~ p o l l u t i o n ~ c o s t s ~ i s ~ a b o u t ~} \$ 0.05$ per mile (Litman, 2015)

*Environmental emission reduction in Pak Rupees is calculated by multiplying the exchange rate i.e. 104.8 rupees per dollar in year 2015 (exchange rate).

Source: Authors' calculations.

The annual reduction in pollution costs is about US $\$ 0.61$ million and US\$2.45 million under the modal shift (i.e. 4 percent of passengers) and the car ownership (Column 6 of Table 3) scenarios (16 percent of passengers) respectively. Our study reveals that reductions in $\mathrm{CO}_{2}$ are less evident because of limited modal shift from private car owners to BRT. The existing network of Lahore BRT is currently only catering to the travel demand of 1.3 percent out of a population of almost 10 million. This points to a need to expand this transit system on other routes of Lahore as well.

Although the overall impact of Lahore BRT is positive, this system has not yet attracted a significant ridership from the among the more educated or higher income groups. Potential barriers may include various 
demand and spatial related constraints as identified by Adeel et al.(2016), as passengers might find it an imperfect substitute for their own private cars, because of inadequate access and insufficient parking at Lahore BRT stations.

Figure 11: Ridership comparison with other worldwide BRT systems

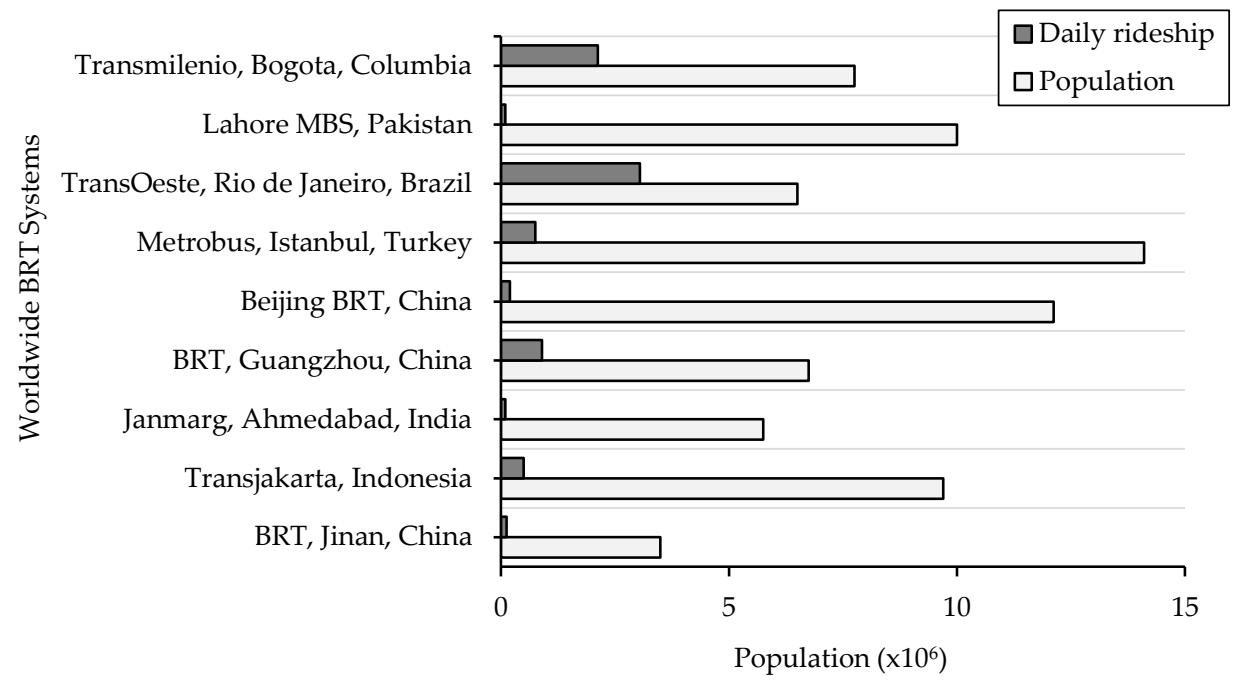

\section{Conclusions and Policy Implications}

Rapid urbanization, urban sprawl and motorization have generated a wide range of transport problems in many large cities in Pakistan. To resolve this, the Government of Pakistan started its first BRT system in Lahore in 2013. This paper attempts to evaluate this project in terms of social, environmental and economic impacts. We have undertaken a survey and our results show that at present most of the users of the Lahore BRT are students and workers belonging to low income categories. In addition, the Lahore BRT plays a role in promoting social welfare as 15 percent of total commuters use this service exclusively for visits to friends and family. Also, since many respondents arrived at Lahore BRT stations daily on foot, the system may help passengers to increase physical activity.

Other considerable positive impacts of this BRT system are related to service efficiency in terms of travel time saving, vehicle cost savings and reductions in environmental emissions. We estimated that on 
average each passenger has saved 23 minutes in a single trip and 46 minutes in an average day. The total economic value of this travel time saving for the entire ridership is approximately US\$7.77 million per year. According to the modal shift statistics (i.e., 4 percent of passengers), the Lahore BRT reduces vehicle miles traveled by about 12.2 million per year and has resulted in vehicle costs saving of about US\$4.3 million per year. The annual reduction in $\mathrm{CO}_{2}$ emissions is about 5 thousand tones reducing pollution costs by about US $\$ 0.33$ million per year.

Our results also found that 16 percent of the total respondents have alternative transport i.e., personal vehicles, but prefer the Lahore BRT, mainly because it is less expensive, more convenient and they wish to avoid traffic. Travelling by the Lahore BRT has reduced the number of vehicles on the road by about 20,800 vehicles leading to a reduction in vehicle miles of about 134.14 thousand vehicle miles. In this case, reductions in $\mathrm{CO}_{2}$ emissions are estimated to be 55 tonnes of $\mathrm{CO}_{2}$ per day, saved vehicle costs are about US\$17.17 million and reduced pollution costs are about $\$ 2.45$ million dollars per year via this transit system. But it is important to note that the Lahore BRT has not succeeded in a significant shift in the modes of transit. The main reason found in our survey was the attitude of private vehicle owners who are less likely to travel by the Lahore BRT transit system because of less comfort, absence of convenient Lahore BRT stations, lack of parking facilities near the stations, short and limited Lahore BRT routes in the city, and the capacity constraints of the system. Therefore, our results suggest expanding and upgrading this transit system to the entire city, building more parking places and developing the surrounding areas with pedestrian tracks near the BRT stations in order to attract more car owners to Lahore's BRT system.

\section{Limitations}

This study has focused on measuring benefits of Lahore's BRT, specifically travel time savings, number of vehicles reduced, vehicle costs savings and environmental emission reduction per year, while we have ignored the costs altogether. For example, time lost during the BRT construction phase and jobs lost due to suspended operations of other urban transport on the BRT route have not been taken into account. Further, our study has only covered the modal shift from personal cars to the Lahore BRT in measuring the benefits and ignored the modal shift 
from other vehicles like buses and vans. Likewise, environmental emissions reductions are calculated using US EPA standards because of the non-availability of reliable estimates in the case of Pakistan. Future studies may improve along these directions. 


\section{References}

Adeel, M., Yeh, A. G. O., and Feng, Z., (2016). Towards an inclusive public transport system in Pakistan. Transport and Communications Bulletin for Asia and the Pacific, 85(September), 33-44. Retrieved from https://www.unescap.org/sites/default/files/Article 3_Towards and inclusive public transport in Pakistan.pdf

Adeel, M., Yeh, A. G. O., and Zhang, F., (2016). Transportation disadvantage and activity participation in the cities of Rawalpindi and Islamabad, Pakistan. Transport Policy. https://doi.org/10.1016/ j.tranpol.2015.12.001

Anthony D. May, (2013). Urban transport and sustainability: The key challenges. International Journal of Sustainable Transportation, 7(3), 170-185. http://dx.doi.org/10.1080/15568318.2013.710136

Aguilra, A., Massot, M.-H., and Proulh, L., (2009). Exploring the relationship between work and travel behavior on weekdays. Transportation Research Record: Journal of the Transportation Research Board, 2135, 69-77. doi: 10.3141/2135-09

Ahmed, A., (2007). Road Safety in Pakistan. Ministry of Communications, Government of Pakistan, National Road Safety Secretariat.

Ali, A. M. (2014). Estimation of traffic congestion cost-a case study of a major arterial in Karachi. In Procedia Engineering. Elsevier B.V., 77, 37-44. doi:10.1016/j.proeng.2014.07.030.

Alpkokin Ergun, M., (2012). Instanbul metro bus: First intercontinental bus rapid transit. Journal of Transport Geography, 24,58-66.

ALMEC, (2012). The project for Lahore urban transport master plan in the Islamic Republic of Pakistan. Government of Punjab, Traffic Engineering and Transport Planning Agency, Lahore Pakistan: ALMEC Corporation, Oriental Consultants. Co. Ltd.

Baghini, M., Ismail, A., Hafezi, M., Seifabad, O., and Almansob, R., (2014). Bus Rapid Transit (BRT) system impacts to environmental quality. 
Research Journal of Applied Sciences, Engineering and Technology, 7(7), 1158-1164. doi: 10.19026/rjaset.7.400.

Carrigan, A., King, R., Velásquez, J. M., Raifman, M., \&Duduta, N. (2013). Social, environmental and economic impacts of BRT systems: Bus rapid transit case studies from around the world. World Resources Institute, EMBARQ. http://www.wrirosscities.org/sites/default/files/ Social-Environmental-Economic-Impacts-BRT-Bus-Rapid-TransitEMBARQ. pdf.

Rapid transit case studies from around the world. World Resources Institute, Washington, DC. Retrieved from www.wricities.org/ /Social-Environmental-Economic-Impacts-BRT-Bus-R.

Cervero, R. (2000). Informal transport in the developing World. UNHABITAT.

Chad, F., William, R., and John, H. G., (2017). Commute mode diversity and public health: A multivariate analysis of 148 U.S. Cities. International Journal of Sustainable Transpotation.1-11. doi: 10.1080/15568318.2017.1321705.

Cochran, W. G., (1963). Sampling Techniques. New York: Unites States: John Wiley and Sons, Inc.

Cropper, M., and Bhattacharya, S., (2012). Public transport subsidies and affordability in Mumbai, India. Urban Studies Research. https://doi.org/10.1155/2012/865972

Currie, G., and Delbosc, A., (2014). Assessing bus rapid transit system performance in Australasia. Research in Transportation Economics, 48, 142-151. doi: 10.1016/j.retrec.2014.09.012.

Dainichi Consultants Inc., (2010). Urban transport policy study for five cities of Punjab province. Government of Pakistan, Urban Sector Policy and Unit Management. Retrieved from www.urbanunit. gov.pk/publicationdocs/32.pdf.

Deng, T., and Nelson, J. D.,(2012). The perception of Bus Rapid Transit: A passenger survey from Beijing Southern Axis BRT Line 1. 
Transportation Planning and Technology, 35(2), 201-219. doi: 10.1080/03081060.2011.651885.

Dell'Olio, L., Ibeas, A., and Cecı'n, P., (2010). Modelling user perception of bus transit quality. Transport Policy, 17, 388-397. Retrieved from www.elsevier.com/locate/tranpol

Diaz,.R., M., C. G., Darido,. E., Schneck,. M., Hardy, J., Bunch,. M., S., Z. 2004. Characteristics of BRT for decision makers. Publication FTA VA-26-7222-2004., US, US Department of Transportation. Retrieved from https://www.transit.dot.gov/sites/fta.dot.gov/ _les/docs/CBRT.pdf.

Dickey, S., (2008). An analysis of new bus rapid transit service and new ridership inLane County, Oregon. Retrieved from University of Oregon: economics.uoregon.edu/wp-content/uploads/sites/4/.../ SarahDickey.pdf.

Dorina, P., and Dominic, S., (2015). Sustainable urban transport in the developing world: Beyond megacities. Sustainability, 7, 7784-7805. doi:10.3390/su7067784.

Eboli, L., and Mazzulla, G., (2011). A methodology for evaluating transit service quality based on subjective and objective measures from the passengers point of view. Transport Policy, 18, 172-181. doi:10.1016/j.tranpol.2010.07.007.

Engineering General Consultants (EGC), (1998). Sectoral Study on Environmental Technology and Infrastructure.

Environmental Protection Agency(EPA), (2014). Greenhouse gas emissions from a typical passenger vehicle. United States Environmental Protection Agency, Office of Transportation and Air Quality. Retrieved from: https://www.epa.gov/greenvehicles/ greenhouse-gas-emissions-typical-passenger-vehicle-0

Esparza, C. J., Diez, M. J., and Perello, C. J., (2016). Prioritization by consensus of enhancements for sustainable mobility in urban areas. Environmental Science and Policy, 55, 248-257. 
Government of the Punjab, Bureau of Statistics, (2015). Punjab Development Statistics. Retrieved 2016, from Bureau of Statistics Punjab: www.bos.gop.pk/publicationreports.

Government of Pakistan, (2016). Pakistan Economic Survey. Retrieved from Ministry of Finance, Government of Pakistan. www.finance.gov.pk/survey/chapters 16/13 Transport.pdf.

Government of Pakistan, (2016). State Bank of Pakistan Annual Report 2015-2016.

Greene, D. L., and Wegener, M. (1997). Sustainable transport. Journal of Transport Geography, 5(3), 177-190.

Haghshenas, H., Vaziri, M., and Gholamialam, A., (2013). Sustainable urban transport assessment in Asian Cities. Current World Environment, 8(2), 221-230. doi:10.12944/CWE.8.2.07.

Hanson, S., and Hu_ J., (1986). Classification issues in the analysis of complex travel. Transportation, 13, 271-293. doi:10.1007/BF00148620.

H. S., and $\mathrm{Hu}_{-}$J., (1982). Assessing day-to-day variability in complex travel patterns. Transportation Research Record, 891, 18-24. Retrieved from URL:http://worldcat.org/issn/03611981.

Hensher, D., and Golob, T., (2008). Bus rapid transit systems: A comparative assessment. Transportation, 35, 501-518. doi:10.1007/s11116-008-9163-y.

Hess, D.,(2009). Access to public transit and its influence on ridership for older adults in two U.S. Cities. Journal of Transport and Land Use, 2(1), 327. Retrieved from http://jtlu.org.

Hu_ J., and Hanson, S., (1990). Measurement of habitual behavior: Examining systematic variability in repetitive travel. In Developments in Dynamic and Activity-based Approaches to Travel Analysis, In a (In P. Jones (ed.): 229-249). 
Imran, M., (2009). Public transport in Pakistan: A critical overview. Journal of Public Transportation, 12(2), 53-83. Retrieved from https://www.nctr.usf.edu/jpt/pdf/JPT12-2Imran.pdf.

Janet, C., Joseph F, C., and Lisa, D. A., (2013). Travel time and subjective well being. Transportation Research Board. doi: 10.3141/2357.

Katrin, H. O.,(2017). Home-end and activity-end preferences for access to and egress from train stations in the Copenhagen Region. International Journal of sustainable Urban Transportation, 1-11. doi: 10.1080/15568318.2017.1317888.

Kitamura, R. and Jamilah, M., (2009). Rapid motorization in Asian cities: Urban transport infrastructure, spatial development, and travel behavior.Transportation, 36, 269\{274.doi:10.1007/s11116-009-9203-2.

Kitamura, R., and T, V. d., (1987). Regularity and irreversibility of weekly travel. Transportation, 14, 227-251. doi:10.1007/BF00837531

Kogdenko, N., (2011). Successfulness of bus rapid transit systems in Asia (ex-post evaluation). Energy Research Centre of the Netherlands, Policy Studies. Retrieved fromwww.ecn.nl/docs/library/ report/2011/o11013.pdf.

Litman, T., (2015). Evaluating public transit benefits and costs (best practices guidebook). Victoria Transport Policy Institute. Retrieved from www.vtpi.org/tranben.pdf.

Litman, T., (2016). The hidden traffic safety solution: Public transportation. American Public Transportation Association.

Litman, T., (2017). Evaluating public transit benefits and costs. Victoria Transport Policy Institute.

Lautso, K., Spiekermann, K., Wegener, M., Sheppard, I., Steadman, P., Martino, A., Domingo, R., and Gayda, S., (2004). Planning and research of policies for land use and transport for increasing urban sustainability (PROPOLIS): Final report to the European Commission. Brussels: EC. 
Mansoor, A., Zahid, I., and Shahzad, L., (2016). Evaluation of social and environmental aspects of Lahore metro bus transit through public opinion. Journal of Environmental Science and Management, 19(2), 27-37. Retrieved from url:https://journals.uplb.edu.ph/index.php/JESAM/ article/view/1554.

Lorita M., (2011). The role of bus rapid transit in improving public transport levels of service, particularly for the urban poor users of public transport: A case of Cape Town, South Africa, Master's Thesis, Faculty of Engineering and the Built Environment, Center for Transport Studies, University of Cape Town.

Mohareb, N., and Felix, M., (2017). Affordable and common modes of transportation in developing cities and their effect on the sustainability of streets. Procedia Environmental Sciences, 37,319-329.

Pas, E., and Sundar, S., (1994). Intrapersonal variability in daily urban travel behavior: Some additional evidence. Transportation, 24, 1-16. doi:10.1007/BF01099436.

Pojani, D., Stead, D., (2015). Sustainable urban transport in the developing world: Beyond megacities. Sustainability, 7, 7784-7805. Doi:10.3390/su7067784.

Mokhtarian, P., Salomon. L., Lothlorien, S.R. (2001). Understanding the demand for travel: It's not purely 'Derived' innovation. The European Journal of Social Science Research, 14(4), 355-380. Doi: 10.1080/13511610120106147.

Punjab Mass Transit Authority, (PMA), (2015). Retrieved from Punjab Masstransit, Authority. http://www.pma.punjab.gov.pk/overview.

Ramadan, A., (2016). Informal transport in Mena, We don't know enough. MENA CTE Journal, 35-41.

Rizelioğlu, M., and Arslan, T., (2020). A comparison of LRT with an imaginary BRT system in performance: Bursa example. Case Studies on Transport Policy. https://doi.org/10.1016/j.cstp.2019.01.007 
Satiennam, T., Jaensirisak, S., Satiennam, W., and Detdamrong, S., (2016). Potential for modal shift by passenger car and motorcycle users towards Bus Rapid Transit (BRT) in an Asian developing city. IATSS Research, 39(2), 121-129.

Serebrisky, T., Gómez-Lobo, A., Estupiñán, N., and Muñoz-Raskin, R., (2009). Affordability and subsidies in public urban transport: What do we mean, what can be done? Transport Reviews, 29(6), 715-739. https://doi.org/10.1080/01441640902786415

Das, S., \& Pandit, D., (2013). Importance of user perception in evaluating level of service for bus transit for a developing country like India: a review. Transport Reviews, 33(4), 402-420.

Statista, (2012). Average wages around the world. Retrieved 2016, from www.statista.com:http://www.statista.com/statistics/226956/ average-world-wages-in-purchasing-power-parity-dollars/.

United Nations Development Programme, (2010). Pakistan Sustainable Transport Project. Retrieved August 2015, from http://pakstran.pk/ docs/Project Document Pakistan Sustainable Transport.pdf.

United Nations Development Programme, (2014). World urbanization prospects. Department of economic and social affairs, population division, New York. Retrieved from http://esa.un.org/unpd/wup/ Highlights/WUP2014-Highlights.pdf.

Wan, D., Camille, K., Jun, L., Aaron, S., and Eric B.B., (2016). Rider perception of a light Bus Rapid Transit system - The New York City Select Bus Service. Transport Policy, 49, 41-55. Doi:10.1016/j.tranpol.2016.04.001

Wang, Y. W., (2013). Study of modal shifts to bus rapid transit in Chinese cities. Journal of Transportation Engineering, 139, 515-523.Available at http://ascelibrary.org/doi/abs/10.1061/

World Health Organziation, (2015). Global status report on road safety. Retrieved from www.who.int/violence injury prevention/road safety status/2015/en/ 
Wright, L., \& Fulton, L., (2005). Climate change mitigation and transport in developing nations. Transport Reviews, 25(6), 691-717.

Wright, L., and Hook, W. 2007. Bus Rapid Transit planning guide. Institute for transportation and development policy, New York. Retrieved 2 10, 2015, from www.nbrti.org/docs/pdf/ITDP BRT Planning Guide.pdf

Yazici, M. A., Levinson, H. S., Ilicali, M., Camkesen, N., and Kamga, C. (2013). A bus rapid transit line case study: Istanbul's metrobüs system. Journal of Public Transportation, 16(1), 8.

Zaman, M. U., (1999). Valuing environmental costs due to automobile pollution in Pakistan. Lahore Journal of Economics, 4 (1):23-40. 
Appendix

\section{Appendix A: Summary of socio-demographic facts, travel choices and travel patterns of Lahore BRT users.}

\begin{tabular}{|c|c|c|}
\hline Socio-demographic Indicators & Categories & Percentage Share \\
\hline \multirow[t]{3}{*}{ Gender } & Male & 80 \\
\hline & Female & 20 \\
\hline & Less than 18 & 18 \\
\hline \multirow[t]{4}{*}{ Age } & $18-34$ & 61 \\
\hline & $35-49$ & 15 \\
\hline & $50-65$ & 5 \\
\hline & Over 65 & 1 \\
\hline \multirow[t]{7}{*}{ Education } & Matric or below & 29 \\
\hline & Intermediate & 27 \\
\hline & Graduate & 25 \\
\hline & Master & 12 \\
\hline & MS/M.Phil. & 3 \\
\hline & Ph.D. & 1 \\
\hline & Other & 3 \\
\hline \multirow[t]{9}{*}{ Occupation } & Civil servant & 5 \\
\hline & Scientific Worker/Teacher & 4 \\
\hline & Private company staff & 13 \\
\hline & Self employed & 5 \\
\hline & Student & 44 \\
\hline & Worker & 18 \\
\hline & Farmer & 0.5 \\
\hline & Retired & 1.5 \\
\hline & Unemployed & 9 \\
\hline \multirow[t]{5}{*}{ Monthly Income: } & No income & 50 \\
\hline & Less than 15,000 & 19 \\
\hline & $15,001-30,000$ & 24 \\
\hline & $30,001-50,000$ & 4 \\
\hline & Above 50,000 & 3 \\
\hline \multirow[t]{2}{*}{ Having car alternative for this trip } & Yes & 16 \\
\hline & No & 84 \\
\hline \multirow[t]{6}{*}{ Travel Frequency } & More than once a day & 53 \\
\hline & 1 time/day & 0.5 \\
\hline & $4-6$ times/week & 13.5 \\
\hline & 1 - 3 times/week & 11 \\
\hline & $1-3$ times/month & 11 \\
\hline & Very seldom & 11 \\
\hline \multirow[t]{4}{*}{ Service Utilization since (Period) } & Less than 1 month & 4.1 \\
\hline & 1 to 3 months & 9.5 \\
\hline & 3 to 6 months & 18.9 \\
\hline & 6 to 9 months & 22.9 \\
\hline
\end{tabular}




\begin{tabular}{llc}
\hline Socio-demographic Indicators & Categories & Percentage Share \\
\hline \multirow{3}{*}{ Choice preferences } & 9 months to 1 year & 9.2 \\
& More than 1 year & 35.4 \\
& Avoid traffic & 23 \\
& Less expensive & 14 \\
& More convenient & 19 \\
& Avoid traffic + Less expensive & 2 \\
& Avoid traffic + More convenient & 2 \\
& Avoid traffic + Less expensive & 21 \\
& + More convenient & \\
& Less expensive + More & 6 \\
& convenient & \\
& other & 13 \\
\hline
\end{tabular}

Source: Authors' Calculations based on survey. 
